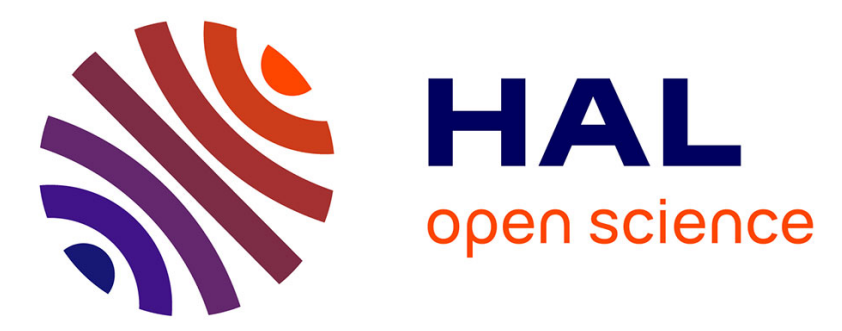

\title{
Pollination ecology of Symplocarpus foetidus (Araceae) in a seasonally flooded bog in Quebec, Canada
}

\author{
Isabelle Barriault, Denis Barabé, Louise Cloutier, Stéphanie Pellerin, Marc
}

Gibernau

\section{- To cite this version:}

Isabelle Barriault, Denis Barabé, Louise Cloutier, Stéphanie Pellerin, Marc Gibernau. Pollination ecology of Symplocarpus foetidus (Araceae) in a seasonally flooded bog in Quebec, Canada. Botany Letters, 2021, pp.1-11. 10.1080/23818107.2021.1909496 . hal-03262116

\section{HAL Id: hal-03262116 https://hal.science/hal-03262116}

Submitted on 16 Jun 2021

HAL is a multi-disciplinary open access archive for the deposit and dissemination of scientific research documents, whether they are published or not. The documents may come from teaching and research institutions in France or abroad, or from public or private research centers.
L'archive ouverte pluridisciplinaire HAL, est destinée au dépôt et à la diffusion de documents scientifiques de niveau recherche, publiés ou non, émanant des établissements d'enseignement et de recherche français ou étrangers, des laboratoires publics ou privés. 


\title{
Pollination ecology of Symplocarpus foetidus (Araceae) in a seasonally flooded bog in Quebec, Canada
}

Isabelle Barriault ${ }^{\mathrm{a}}$, Denis Barabé ${ }^{\mathrm{a}}$, Louise Cloutier ${ }^{\mathrm{b}}$, Stéphanie Pellerin ${ }^{\mathrm{a}}$ and Marc Gibernau ${ }^{\mathrm{c}}$

${ }^{a}$ IRBV, Jardin botanique de Montréal, Université de Montréal, 4101 Sherbrooke Est, Montreal H1X 2B2, QC Canada; 'bollection entomologique Ouellet-Robert de l'Université de Montréal, Départment de Sciences Biologiques, 4101 Sherbrooke Est, Montreal H1X 2B2, QC Canada; ${ }^{\mathrm{c}} \mathrm{CNRS}$ - University of Corsica, Laboratory of Sciences for the Environment (SPE - UMR 6134), Vignola, Route des Sanguinaires, 20000 Ajaccio, France.

CONTACT Marc Gibernau; gibernau_m@univ-corse.fr ; CNRS - University of Corsica, Laboratory of Sciences for the Environment (SPE - UMR 6134), Vignola, Route des Sanguinaires, 20000 Ajaccio, France

\begin{abstract}
The pollination ecology of Symplocarpus foetidus (L.) W. Salisbury was studied in a seasonally flooded bog under a maple cedar forest in Quebec (Canada) in 2008 and 2009. The protogynous anthesis duration ranged from 15 to 20 days with, chronologically, a female phase of about 5 days, a bisexual phase of 2 days, and a male phase of 9 days. The spadix temperature differences with ambient air were higher during the female phase (mean of $13.6^{\circ} \mathrm{C}$ ) than during the bisexual and male phases (mean of $4.5^{\circ} \mathrm{C}$ ). The air inside the floral chamber was warmed by the heating spadix, particularly during the female phase $\left(\sim 6^{\circ} \mathrm{C}\right.$ warmer than ambient air). The high
\end{abstract}


temperatures were somewhat maintained through nighttime during the female phase, whereas they occurred only in daytime during the bisexual and male phases.

The average natural fruit and seed sets were relatively low (18.2\% and $14 \%$ respectively), and the fruit set varied between years (13\% in 2008 vs. $31 \%$ in 2009). Since spontaneous selfpollination is a rare reproductive event, sexual reproduction in Symplocarpus foetidus relies mainly on insect cross-pollination. Pollination is probably generalist considering the large variety of Coleoptera and Diptera families attracted to the plant, such as Chironomidae, Sphaeroceridae, Mycetophilidae, Phoridae, Drosophilidae, Chloropidae and Anthomyiidae. Since many different insect types visit the inflorescences, it is unclear whether this pollination system is a deceptive interaction (its unpleasant floral scent is typical of other deceptive Araceae), a breeding site mutualism (developing larvae have been observed on the inflorescences), or a combination of the two.

KEYWORDS: anthesis, flowering sequence, thermogenesis, visiting insects, fruiting success. 


\section{Introduction}

Angiosperms currently represent $\sim 90 \%$ of all actual land plants. While the timing of their origin remains up for debate, there is little doubt that insect pollination accelerated angiosperm radiation (Hernández-Hernández \& Wiens 2020; van der Kooi \& Ollerton 2020). Insect pollination is the rule in Araceae; exceptions are rare, and it occurs from the early-diverging genera such as Lysichiton Schott and Symplocarpus Salisbury ex Nuttal (Chartier et al. 2014; Gibernau 2016). In several insect-pollinated plant families, the reproductives structures can increase their own temperature during anthesis. Thermogenesis occurs in single flowers (Annonaceae, Aristolochiaceae, Hydnoraceae, Illiceaceae, Magnoliaceae, Nelumbonaceae, Nymphaeaceae, Rafflesiaceae and Schisandraceae), inflorescences (Araceae, Arecaceae and Cyclanthaceae), or cones (Cycadaceae and Zamiaceae) (Seymour 2010). Araceae is probably the plant family comprising the highest number of thermogenic species. It is noteworthy that thermogenesis occurs during the anthesis in relation to pollination and should be considered as a reproductive floral trait. Among early-diverging Araceae, the genus Symplocarpus. (Araceae), also known as skunk cabbages, encompasses five temperate species: four are distributed in East Asia (S. renifolius Schott ex. Tzvelev (syn. S. foetidus (L.) Nutt.) var. latissimus (Makino) S. Hara), S. nipponicus Makino, S. nabekureansis Otsuka \& K/Inoue, S. egorovii N.S. Pavlova \& V.A. Necheaev) and one in northeastern North America (S. foetidus (L.) W. Salisbury) (Govaerts and Frodin 2002; Nie et al. 2006; Lee et al. 2010).

In northeastern America, Symplocarpus foetidus flowers in early spring before the leaves emerge, when there is still a considerable amount of snow on the ground. The fruits ripen in the following summer (Williams 1919). The inflorescence is located on a short, erect peduncle that emerges close to the ground. The spathe is generally dark or mottled purple, conchiform, convolute in its lower part and wide open in its upper part, with the apex rostrate and curved forward. The 
spadix is subglobose, yellowish to purplish, partially exposed or sometimes completely hidden within the spathe, and the monolocular ovaries contain a single ovule (Mayo et al. 1997). Protogynous anthesis has not been adequately studied in S. foetidus, as it has been in its Asian congenerics (Uemura et al. 1993; Wada and Uemura 2000; Uemura and Sugiura 2007; Takeda et al. 2018). It has nonetheless been reported to last a few weeks (Knudson 1974; Thorington 2000). In a flowering survey, $43 \%$ of the mature individuals observed $(N=113)$ produced one inflorescence, $45 \%$ produced two and $12 \%$ three or more; in the latter cases, flowering occurred sequentially (Thorington 2000). Pollinators have not yet been characterized, but a wide variety of arthropods (e.g., bees, beetles, flies, spiders, springtails, stoneflies and thrips) were reported to visit the inflorescences (Trelease 1879; Williams 1919; Knutson 1979; Kevan 1989; Thorington 2000). Fly larvae can also be observed in and on many inflorescences (Thorington 2000). In a different population, it has been shown that fly larvae can belong to 19 species from 7 Diptera families, mainly Drosophilidae (Drosophila spp Fallén and Scaptomyza spp Hardy) that feed on the rotting portions of the skunk cabbage's leaves, petioles, and flowers; some of them are specialized for this plant host (Jaenike 1978; Grimaldi and Jaenike 1983). Thus, the inflorescence represents an oviposition site for many phytophagous Diptera; however, their role as pollinators is not established. Wind pollination through intra-spathe cyclonic vortex has been suggested (Camazine and Niklas 1984) but due to limited supposed selfing capacity, it is unlikely that wind is a primary pollen vector (Thorington 2000). Also, the pollination system is not well understood and natural pollination success appears to be very low. For instance, out of 226 inflorescences only 40 (18\%) developed mature fruits, suggesting low pollination efficiency, and only 14 of these fruits completed their development, indicating bad pollination quality and/or fruit predation (Thorington 2000). 
The most striking and studied eco-physiological trait of $S$. foetidus is the floral thermogenesis which occurs during the anthesis. The inflorescences of this species are among the most precise thermoregulating reproductive structures found in plants (Seymour and Blaylock 1999; Seymour 2010). The spadix of Symplocarpus foetidus can maintain its temperature within a $3.6^{\circ} \mathrm{C}$ range (between $22.7-26.3^{\circ} \mathrm{C}$ ) over a large gradient of ambient air temperatures (from -10 to $+27^{\circ} \mathrm{C}$ ) for at least 14 days. Such thermoregulation resulted in a spadix temperature 15 to $35^{\circ} \mathrm{C}$ higher than ambient air temperature (Knutson 1972, 1974; Seymour and Blaylock 1999; Ito et al. 2004; Seymour 2004; Takahashi et al. 2007; Seymour 2010). Thermogenesis has been assumed to attract and / or reward pollinators, to act as a heated scent diffuser for the inflorescence, and / or to be an adaptation to cold temperate climate, protecting the inflorescence from frost damage or boosting growth in this early flowering species (Knutson 1972; Moodie 1976; Seymour and Blaylock 1999; Thorington 2000). The scent of S. foetidus has been described in various ways by different authors, likely because the spathe and the spadix seem to release different scents. The spathe is reported to smell like apples (sweetish), turnips or garlic, while the spadix emits a more nauseating kind of mephitic scent similar to that of mammalian feces or carrion (Trelease 1879; Williams 1919; Knutson 1979; Camazine and Niklas 1984; Kevan 1989). The unpleasant odour of the spadix is dominated by dimethyl disulfide (Kozen 2013), a classic volatile organic compound produced by carrion flowers and reminiscent of rotten meat (Urru et al. 2011).

This study aimed to document the pollination biology of Symplocarpus foetidus in one Canadian population. Our specific questions were: i) how long does anthesis last and is thermogeny related to the sexual flowering phases? ii) Do female and male phases overlap, allowing selfpollination? iii) Which insect families visit and pollinate the inflorescences? iv) How successful is natural fruit set? 


\section{Material and Methods}

\section{Studied Site}

The pollination ecology of Symplocarpus foetidus (L.) W. Salisbury was studied in a population growing naturally in a seasonally flooded bog under a maple (Acer rubrum L.) and cedar (Thuja occidentalis L.) forest located in Lanoraie (Quebec, Canada; GPS coordinates: 45.958N, 73.344W), an area covering 2,500 $\mathrm{m}^{2}$. The ground was irregular, presenting several mounds and depressions. The herbaceous layer was dominated by Onoclea sensibilis L., Osmundastrum cinnamomeum L. C. Presl., S. foetidus, Caltha palustris L., Plagiomnium ellipticum (Brid.) T.J. Kop. and Climacium dendroides (Hedw.) F. Weber \& D. Mohr. A voucher specimen of S. foetidus from this population has been deposited at the Marie-Victorin Herbarium - University of Montréal (MT00022533). The study was conducted over two successive years in 2008 and 2009. In the first year, the monitoring, measurements and collections were performed between March $20^{\text {th }}$ and June $4^{\text {th }} 2008$, with the last survey on August $19^{\text {th }}$ to check the fruit set. It is noteworthy that the site was under $87 \mathrm{~cm}$ of snow on March $8^{\text {th }} 2008$, and there was still snow on the ground during the study. The following year, the field study took place between March $4^{\text {th }}$ and June $18^{\text {th }} 2009$, with a last survey on August $14^{\text {th }}$ to check fruit set. On March $14^{\text {th }} 2009$, a few patches of ice remained on the ground, and on April $14^{\text {th }}$ closed spathes were observed on frozen ground while open ones were found on thawed soil. The last snowfall occurred on April $4^{\text {th }}$ in 2008 , compared to March $5^{\text {th }}$ in 2009 , indicating a one-month difference in winter conditions during these two successive years.

\section{Spadix Morphometry}

The morphometry of the subglobose spadix (Fig. 1) was studied on 39 inflorescences collected randomly on different plants. Two parameters were measured, the spadix length and its diameter, using a digital calliper. The spadix volume was then estimated using the following 
ellipsoid formula: $4 / 3 \times \pi \times$ length $\times$ diameter $^{2}$. The total number of bisexual flowers on each inflorescence was later counted in the laboratory under a stereomicroscope.

\section{Anthesis}

Each of the minute flowers ( $5 \mathrm{~mm})$ of $S$. foetidus is bisexual and composed of four tepals, four stamens, and one ovary (Mayo et al., 1997). They are protogynous, with stigma receptive before pollen dehiscence. The different floral phases were recorded every day on 24 labelled inflorescences, from the spathe's opening until the end of pollen release. Once the spathe is open, the four floral phases were characterized: immature (stigmas not visible), female or pistillate (stigmas receptive: turgid and wet, exerted above the tepals; Figs. 1A-B), bisexual (some stigmas still receptive and several anthers release some pollen; Fig. 1C), and male or staminate (stigmas no longer receptive, full pollen release from all the anthers; Fig. 1D). The duration of each floral phase (immature, female, bisexual and male) was measured and the emission of scent (detected by nose) was reported. The survey started on April $13^{\text {th }}$ and finished on May $2^{\text {nd }} 2009$, followed by a last survey on August $14^{\text {th }}$ to check for fruit formation. All mature infructescences were collected and the number of sired seeds counted later in the laboratory.

\section{Floral Thermogenesis}

The capacity of the spadix to increase its temperature was recorded throughout anthesis on four inflorescences. Two probes were inserted through a small cut within the spathe to allow temperature recording prior to the spathe opening. The first probe was inserted about $5 \mathrm{~mm}$ deep into the spadix, and the second one was suspended inside the floral chamber (i.e., the space between the spadix and the spathe). A third probe recorded air temperatures in the shade, sheltered by a leaf blade. Temperatures from the spadix, the air inside the floral chamber and the ambient air were recorded every 30 min with Digi-Sense ${ }^{\circledR}$ DualLogR ${ }^{\circledR}$ thermocouple thermometers. Tulle bags were 
placed to shade inflorescences from direct sunlight. These four inflorescences were also checked for fruit production in August of the same year. All mature infructescences were collected and the number of sired seeds counted later in the laboratory.

\section{Reproductive Success and Self-Pollination}

In 2008 and 2009, 45 inflorescences were labeled and left untouched until the end of the survey to quantify natural reproductive success. The capacity of S. foetidus to spontaneously selfpollinate was tested by bagging closed inflorescences in fine mesh bags for the duration of the anthesis. In 2008, 20 inflorescences were bagged: nine on March $21^{\text {st }}$, six on March $24^{\text {th }}$, and five on March $29^{\text {th }}$. All tested inflorescences (bagged and unmanipulated) were checked on August $19^{\text {th }}$ 2008 for fruit abortion or production. In 2009, 20 inflorescences were bagged on March $26^{\text {st }}$ and checked on August $14^{\text {th }}$ for fruit abortion or production. All mature infructescences were collected and the number of sired seeds counted later in the laboratory. The fruit sets between unmanipulated and bagged inflorescences were compared for each study year with $\mathrm{Chi}^{2}$ tests, whereas the seed numbers obtained for each treatment in each study were compared with Kruskal-Wallis tests using Past 4.03 statistical software (Hammer et al., 2001).

\section{Local Entomofauna and Diversity of Visiting Insects}

The diversity of active insects on the study site was estimated with a trapping experiment throughout the flowering period. Ten white plastic trays were placed randomly every $5 \mathrm{~m}$ within the growth area of the $S$. foetidus population. Twice a week (every 3-4 days), the plates' contents were filtered and conserved in labeled vials containing $70 \%$ alcohol (2 vials per week). Sampling started on March $29^{\text {th }}$ and ended on May $22^{\text {nd }} 2008$.

The diversity of visiting insects associated with 20 marked inflorescences (in 2008) and 15 marked inflorescences (in 2009) was estimated by collections within the spathe with a pooter (mouth 
aspirator), conducted twice a week (2008) or every day (2009) between 11:00 a.m. and 2:00 p.m. throughout anthesis (regardless of floral phase). Collected specimens were conserved in $70 \%$ ethanol (2008) or killed in ethyl acetate (2009) for subsequent pollen load counts. In 2008, sampling started on March $24^{\text {th }}$ and ended on May $22^{\text {nd }}$, followed by a last check on August $19^{\text {th }}$ for fruit abortion or production. In 2009, sampling started on April $13^{\text {th }}$ and ended on May $6^{\text {th }}$, and the plants were checked on August $14^{\text {th }}$ for fruit abortion or production. All mature infructescences were collected and the number of sired seeds was counted.

Insects were identified under a stereomicroscope mostly to order level, but we reached family level for dipterans (McAlpine et al. 1981). All collected insects were deposited at the OuelletRobert Entomological Collection of the University of Montréal.

\section{Insect Pollen Loads}

The visiting insects collected in 2009 (see above) were killed with ethyl acetate and kept dry in separate vials to count their pollen loads under a stereomicroscope. Moreover, the floral phase of the inflorescence visited by the insect(s) was noted: female (stigma receptivity) or male (pollen release). The frequencies of insects collected in the female phase vs the male phase were compared with a Chi² test using Past 4.03 statistical software (Hammer et al., 2001).

\section{Results}

\section{Spadix Morphometry}

The mean $( \pm \mathrm{SD})$ spadix height was $2.30 \pm 0.52 \mathrm{~cm}$ (range $1.23-3.4, N=39)$ and the mean diameter was $1.53 \pm 0.32 \mathrm{~cm}$ (range $1.00-2.10$ ). The mean calculated spadix volume was $25.35 \pm 14.46 \mathrm{~cm}^{3}$ (range 5.36 - 57.26) and the mean number of flowers per spadix was $83 \pm 25$ (range 34 - 142). 


\section{Anthesis}

The total duration of the flowering sequence ranged from 15 to 20 days (average 18.1 days \pm 1.6 $\mathrm{SD}, N=24)$. In the first phase (or immature phase) in which the spathe unfolds $(2.3 \pm 0.8$ days) there was no sign of stigma receptivity; the spadix was cream-coloured (pale yellow), sometimes with burgundy lines. During the second (female) phase, which lasted 4 to 9 days (5.2 \pm 1.7 days), stigmas appeared to be moist (stigmatic drops) and receptive (white papillae); the spadix colour was cream at the base and entirely burgundy at the top (Figs. 1A-B). The third phase was a short bisexual phase (1.6 \pm 0.8 days). Stigmas from lower flowers were still receptive (white papillae, stigmatic drops) when the fully exerted anther filaments of the upper flowers started to release some pollen (Fig. 1C). The fourth and last phase was the male phase, which lasted from 5 to 12 days $(9.1 \pm 2.1$ days); the spadix was yellow with traces of burgundy and a large amount of pollen was released from all the anthers, falling on the inner spathe surface (Fig. 1D). The maturation of the stigmas and the extension of anther filaments started from the top and progressed downwards (i.e., basipetally). On the first day, only about the upper $1 / 4$ of the spadix was functional, then on the next day half of it, and so on. On some occasions, the stamens facing the spathe opening did not release pollen whereas the ones facing backwards, protected by the spathe within the floral chamber, did release pollen. This may be due to the flowers facing the spathe opening being exposed to cold or rain. In one occurrence, for yet unknown reasons, only the upper half of the stamens released the pollen.

\section{Floral Thermogenesis}

The four thermogenic records were similar, despite some quantitative temperature variations. Heat production by the spadix showed a diurnal pattern repeated throughout anthesis. Each day during anthesis, the spadix temperature increased gradually to reach a maximum around 1:00 - 1:30 p.m. (Fig. 2A). However, the maximum temperature differences occurred at different times and did 
not coincide with the maximum temperatures (Fig. 2B). An important time shift in the temperature pattern was observed during anthesis. During the female phase, the high temperatures were somewhat maintained during nighttime (between 6:00 p.m. and 10:00 a.m.), whereas the same thing occurred in daytime (between 10:30 a.m. and 7:00 p.m.) during the bisexual and male phases (Fig. 2). Moreover, the temperature pattern varied during the anthesis. Continously high spadix temperatures were recorded during the female phase, whereas daily distinct temperature peaks occurred during the bisexual and male phases (Fig. 2A). The spadix reached temperatures up to $27.8^{\circ} \mathrm{C}$ during the female phase (mean: $\left.21.6 \pm 2.1^{\circ} \mathrm{C}\right), 15^{\circ} \mathrm{C}$ during the bisexual phase $\left(7.7 \pm 4.5^{\circ} \mathrm{C}\right)$ and $28.9^{\circ} \mathrm{C}$ during the male phase $\left(12 \pm 6.6^{\circ} \mathrm{C}\right)$ while the mean air temperature during the same period was $8^{\circ} \mathrm{C}( \pm 5.2)$. The thermogenic spadix also resulted in the synchronous warming of the air within the floral chamber (Fig. 2A). The air inside the floral chamber reached temperatures up to $19.8^{\circ} \mathrm{C}$ during the female phase (mean: $\left.12.2 \pm 3.7^{\circ} \mathrm{C}\right), 11.2^{\circ} \mathrm{C}$ during the bisexual phase $(5.5 \pm$ $\left.2.3^{\circ} \mathrm{C}\right)$ and $17.2^{\circ} \mathrm{C}$ during the male phase $\left(9.4 \pm 3.9^{\circ} \mathrm{C}\right)$ while the mean air temperature during the same period was $8^{\circ} \mathrm{C}( \pm 5.2)$.

Spadix thermogenesis started before the spathe opened, since the spadix temperature was about 8 to $10^{\circ} \mathrm{C}$ higher than that of ambient air before spathe opening (Fig. 2B). Once the spathe was open, the temperature difference remained at the same level $\left(\sim 8^{\circ} \mathrm{C}\right)$ during the immature phase. However, it drastically increased at the beginning of the female phase, with the temperature of the spadix reaching up to $18.2^{\circ} \mathrm{C}$ above ambient air (Fig. 2B). During the female phase, the spadix temperature difference maximum decreased every day and was down to $13^{\circ} \mathrm{C}$ above ambient air temperature on the last day. Simultaneous to the temperature increase, the plant emitted a mixed odour reminiscent of carrion (inflorescence) and onion (leaves). During the bisexual phase, the temperature of the spadix dropped and shifted to a different pattern with no notable warming during the night. This new pattern was maintained until the end of the male phase. The temperature difference regularly decreased from a maximum of $\sim 12^{\circ} \mathrm{C}$ down to $\sim 4^{\circ} \mathrm{C}$ above ambient air 
temperature (Fig. 2B). Afterwards, no notable heat was recorded and the inflorescence temperature remained equal to ambient air temperature. Although there were temperature fluctuations in both phases, spadix temperature differences were higher during the female phase (mean temperature difference $13.6 \pm 2.8^{\circ} \mathrm{C}$ ) than during the bisexual and male phases (mean temperature difference $4.5 \pm 3.1^{\circ} \mathrm{C}$ ). The air temperature in the floral chamber was $\sim 6^{\circ} \mathrm{C}$ warmer than ambient air during the female phase. It dropped to 2 to $5^{\circ} \mathrm{C}$ warmer than ambient air during the bisexual and male phases and no notable temperature difference was recorded after that (Fig. 2B).

\section{Reproductive Success \& Self-Pollination}

The fructification rate varied among the experimental treatments (Table 1). For unmanipulated inflorescences, the fructification rates (i.e. number of infructescences) varied considerably between the two consecutive reproductive seasons ( $13 \%$ in 2008 vs $31 \%$ in $2009, N=45)$. It is worth noting that in $2009,37 \%$ of the infructescences aborted before ripeness. Overall, $18.2 \%$ of the 137 observed inflorescences produced an infructescence (Table 1$)$. On the other hand, only one $(2.5 \%)$ of the 40 inflorescences that were bagged during the entire flowering duration produced 12 seeds, indicating that either self-pollination or agamospermy are very unlikely (Table 1). In 2008, the number of infructescences (i.e. fruit set) was not different between unmanipulated inflorescences and bagged ones $\left(\chi_{(2,2)}^{2}=1, p=0.32\right)$. On the other hand, unmanipulated inflorescences produced significantly more infructescences than bagged ones did in $2009\left(\chi_{(2,2)}^{2}=7.93, \mathrm{p}=0.0048\right)$. The number of sired seeds per infructescence varied greatly $(1-46)$, with a calculated mean of 12 . Also, in 2008 , the number of sired seeds was not different between unmanipulated inflorescences and bagged ones $(\mathrm{KW}: \mathrm{H}=0.14, \mathrm{p}=0.45)$. However, unmanipulated inflorescences produced significantly more seeds than bagged ones did in $2009(\mathrm{KW}: \mathrm{H}=3.96, \mathrm{p}=0.0056)$. Seed viability was not tested. 


\section{Entomofauna Diversity}

In 2008, a total of 5,718 arthropods (105 Arachnida, 273 Collembola, and 5,340 Insecta) were collected during the trapping experiment. (Table 2). Diptera represented 93\% of the overall insects captured, followed by Coleoptera (3.6\%). Among the 20 recorded dipteran families, Chironomidae was the most abundant family (73.3\%), followed by Mycetophilidae (11.6\%). Phoridae, Psychodidae and Sciaridae, together accounting for about $12 \%$ of all Diptera, were the only other numerically significant families (Table 2).

\section{Diversity of Visiting Insects}

In total, 364 and 375 visiting arthropods respectively were collected from 20 inflorescences in 2008 and from 15 in 2009. The most represented class was Insecta (81\% in 2008 and $86 \%$ in 2009) followed by Arachnida (11.8\% and 6.6\%) and Collembola (6.3\% and 7.2\%) (Table 2). The insects belonged to several different orders: Coleoptera (6.4\% in 2008 and 6.7\% in 2009), Hemiptera (2.4\% and $1.9 \%)$, Hymenoptera (3\% and $4.5 \%)$, Lepidoptera $(0.3 \%$ and $0.56 \%)$, Thysanoptera (2\% and $0.6 \%$ ), but Diptera was the most abundant order for both years (85.8\% and $85.6 \%$ respectively). Diptera were represented by 18 families in 2008 and 17 in 2009 (Table 2), and among them Chironomidae was the most well-represented with $64 \%$ of the total number of visiting insects. The other noteworthy dipteran families associated with the inflorescences of S. foetidus at our study site varied between the two years. In 2008, there were Mycetophilidae (6.4\% of all Diptera), Sciaridae (4.8\%), and Psychodidae (4\%); whereas in 2009 the less-abundant families were Sphaeroceridae (13\%), Mycetophilidae (5.4\%), Chloropidae (4.7\%), Drosophilidae (4\%), and Phoridae (4.7\%).

Over the entire flowering period, $32.6 \pm 17.6 \%$ (SD) of the inflorescences were visited at least once per day in 2008 , compared to $28.6 \pm 18.5 \%$ in 2009 . On both years, a mean number of $1.3+-$ 0.6 (SD) insects were found inside these inflorescences at the time of collection. Our 2009 survey showed that more insects were collected within inflorescences during the male phase than during 
the female phase (Table 2). Inflorescences with receptive stigmas were frequently visited by Chironomidae (50\%), Sphaeroceridae (18.5\%), Chloropidae (4.4\%), Mycetophilidae (3.3\%) and various Coleoptera (6.5\%) (Table 2). On the other hand, inflorescences releasing pollen were frequently visited by Chironomidae (49.3\%), Sphaeroceridae (8.2\%), Mycetophilidae (5.2\%), Drosophilidae (3.5\%) and various Coleoptera (6.5\%) (Table 2).

\section{Insect Pollen Loads}

A total of 296 specimens were examined for pollen loads. They were collected in similar proportions from male and female phases $\left(\chi_{(2,2)}^{2}=0.18, \mathrm{p}=0.68\right)$. For 12 out of the 17 dipteran families observed, at least one pollen-carrying specimen was found (Table 3). Globally, only 37\% of the examined insects carried pollen grains. Absolute pollen quantities in the loads were evaluated and showed that three Diptera families carried larger quantities of pollen (average $>50$ grains): Anthomyiidae, Chloropidae and Sphaeroceridae, but also Hymenoptera and Coleoptera (Table 3). Flies from the Chironomidae, Mycetophilidae, and Drosophilidae families could also carry a nonnegligible quantity of pollen (average 9 - 12 grains).

The main potential pollinators were Coleoptera and among Diptera: Drosophilidae, Sphareroceridae, Chironomidae or Mycetophilidae, when taking into account their abundance in both floral sexual phases and their pollen loads (Table 3). Secondary potential Diptera pollinators were Anthomyiidae, Chloropidae, Diastatidae, Drosophilidae, Ephydridae, and Phoridae (Table 3). On average, the pollen loads of insects visiting male phase inflorescences was higher $(47.5 \pm 112.9$ $(\mathrm{SD})$, range $1-650, N=80)$ than those visiting female phase inflorescences $(9.4 \pm 17$, range $1-90$, $N=30)$. 


\section{Discussion}

Natural reproductive success was relatively low for both the fruit and seed sets, and with large inter-annual variations (two-fold). Spontaneous self-pollination is a rare reproductive event in Symplocarpus foetidus. Hence, this species sexual reproduction relies heavily on cross-pollination. It appears that insects, in particular Diptera, were the most abundant inflorescence visitors. Pollination is probably generalist, considering the high number of attracted Coleoptera and Diptera families. Hymenopterans, which were not observed visiting inflorescences during the female phase, were assumed to play the role of pollen robbers rather than pollinators. Most of the dipteran families collected within the floral chambers of the inflorescences of $S$. foetidus were probably opportunistic visitors, since only eight out of the 30 families identified were collected during both phases of anthesis while carrying pollen. From an abundance point of view, these eight families represented more than $70 \%$ of all the visiting insects. Namely, the most probable pollinators are among the Chironomidae, Sphaeroceridae, Mycetophilidae, Phoridae, Drosophilidae, Chloropidae, and Anthomyiidae. Our results suggest that the Sciaridae, Psychodidae, Ephydridae, and Diastatidae should be considered as secondary pollinators. In contrast to the results documented in a study conducted in Massachusetts (Thorington, 2000), no stoneflies (Nemouridae, Plecoptera) were collected in Quebec. The main dipteran visitors of another North American aroid, Arisaema triphyllum (L.) Schott (Jack-in-the-pulpit), which also flowers at the end of April-early May in Quebec, were also Mycetophilidae, Chironomidae, and Sciaridae, plus Cecidomyiidae; Thysanoptera and Coleoptera were also abundant in one population (Barriault et al. 2010). Interestingly, one study on Diptera breeding on skunk cabbage in Maine and New York state (Grimaldi and Jaenike 1983) showed that several families use the skunk cabbage as a breeding host plant. From leaves and petioles, $65 \%$ of emerging diptera were Drosophilidae with a large majority of Scaptomyza graminum Fallén, but also Psychodidae (11\%), Ceratopogonidae (11\%), 
Cecidomyiidae (6.8\%) and Chironomidae (4.8\%). From the inflorescences (described as flowers), Drosophilidae were also dominant (52.6\% of emerging diptera), half of them being Drosophila recens Wheeler; two other families were abundant, namely Chloropidae (23.3\%) and Psychodidae (21\%) (Grimaldi and Jaenike 1983). It appears that the S. foetidus represents a pivotal resource, as an oviposition site, for several dipteran taxa (Grimaldi and Jaenike 1983). In our survey, Drosophilidae (3\%), Psychodidae (3\%) and Chloropidae (4\%) were not frequently collected, whereas Chironomidae (64\%) were by far the most abundant floral visitors. It is thus not clear whether these Diptera ovipositing on the inflorescences are also pollinators.

Given the unpleasant floral scent, the pollination system could be related to carrion-mimicry. That would explain its high attractiveness to flies with saprophagous larvae such as Sphaeroceridae, Anthomyiidae, Chironomidae, Drosophilidae, Phoridae, Mycetophilidae, Psychodidae, and Sciaridae. It appears that the unpleasant spadix odour is mainly caused by dimethyl disulfide (Kozen 2013), a compound typical of the smell of fetid meat. While deceptive attraction may be responsible for some of the visiting flies among the various families (Sphaeroceridae, Anthomyiidae, Sciaridae, Phoridae, Chironomidae (in part), and Mycetophilidae), many of the Diptera attracted to the strongly scented inflorescences might actually be using them as a breeding site (Drosophilidae, Psychodidae, Chloropidae, Ceratopogonidae, Cecidomyiidae, and Chironomidae (in part)). Therefore, the pollination system of $S$. foetidus might be an original combination of breeding site and deceptive pollination strategies. Further work is needed to better understand this pollination system, such as its specificity, the contribution of each visiting species to pollination success, and/or geographical variations of the interactions.

The relatively low natural fruit set of $S$. foetidus observed in our study is similar to what was documented during a study conducted in Massachusetts (18.2\% and 6\%, respectively) (Thorington 2000). Moreover, our study has showed that the fructification rate varied considerably (two-fold) between two consecutive yearly reproductive periods. In addition to a low fruit set, a reduced 
number of sired seeds was also observed. Since the ovaries of $S$. foetidus are monolocular and contain a single ovule (Mayo et al. 1997), the number of female flowers is equal to the number of potential seeds. In our studied population, the average potential number of seeds was 83 . Thus, it appears that on average only $14 \%$ of the flowers per inflorescence (and a maximum of 55\%) are pollinated or able to develop seeds.

Several hypotheses can be proposed to explain the low natural seed set of $S$. foetidus in our study population. First, insect cross-pollination may be inefficient. The inflorescence visitation rate per day was low (33\% of inflorescences visited per day) and when insects did visit, only one or two specimens could be observed inside the inflorescence. Moreover, most insects visiting inflorescences during their female phase $(65 \%)$ were not carrying pollen. When they did, the pollen loads were small ( $87 \%$ of insects with pollen carried $1-8$ pollen grains). Secondly, contrary to many other aroid species that use deception to achieve pollination, the overall floral morphology of $S$. foetidus does not present any obvious trapping device (Bröderbauer et al. 2012). The inflorescence cannot retain visiting insects within the spathe, and thus they can easily leave the inflorescence, which in turn reduces the probability of insects coming into contact with receptive stigmas. On the other hand, spadix thermogenesis could represent a heat reward for insects during the cold Canadian spring, increasing the time the insects spend over the flowers. Thirdly, it has been documented that the spadix may represent an oviposition site for several species of drosophilids. Their larvae could damage the developing infructescences, inducing seed abortion. An average of nine larvae per spadix were found in S. foetidus populations in the states of Maine and New York (Grimaldi and Jaenike 1983). Fruit abortion is an important factor in the reproductive dynamics of $S$. foetidus, since $36 \%$ of the labelled infructescences did not reach maturity. A higher abortion rate $(65 \%)$ was found in a natural population in the state of Massachusetts (Thorington 2000). In conclusion, the relatively low fruit and seed sets could result from a combination of pollen limitation, flower predation by fly larvae, resources availability, and climatic conditions during reproductive season 
and fruit maturation. Hand-pollination experiments could enhance our comprehension of the impact of pollen limitation, weather conditions, and saprophage-related damage on fruit set. In Arisaema triphyllum, a species that also exhibits a low floral visitation rate, hand-pollination experiments resulted in a significant increase in fructification rate from $32 \%$ to $80 \%$, suggesting pollen limitation is probably the main reproductive limitation (Barriault et al. 2010).

Heating due to floral thermogenesis may thus be important for insect attraction, not only as a floral scent diffuser but also as a heat reward. During the end of April and May, ambient air temperatures during the night were cold, regularly dipping below $5^{\circ} \mathrm{C}$, while air temperature within the floral chamber was $\sim 6^{\circ} \mathrm{C}$ warmer than ambient air during the female phase. It was still $2-5^{\circ} \mathrm{C}$ warmer than ambient air during the bisexual and male phases. The heated spadix could thus protect insects, both visiting adults and developing larvae, from low ambient temperatures. Our methodology does not allow to measure any thermoregulatory response of the spadix, but our results appear to somewhat differ from those of previous studies. Our temperature records showed that the floral thermogenesis period lasted up to two weeks whereas previous studies on S. foetidus observed floral thermogenesis lasting for at least 14 days (Knutson 1972, 1974; Seymour and Blaylock 1999; Seymour 2004). Moreover, spadix temperatures showed substantial diurnal deviations $\left(\sim 20^{\circ} \mathrm{C}\right)$, particularly during the bisexual and male phases. Our results seem to be in disagreement with previous studies highlighting a reduced spadix temperature variation within a $3.6^{\circ} \mathrm{C}$ range $(22.7-$ 26.28 ${ }^{\circ}$ C) (Knutson 1972, 1974; Seymour and Blaylock 1999; Ito et al. 2004; Seymour 2004; Takahashi et al. 2007; Seymour 2010); such a pattern seemed to correspond to the temperature records during the female phase. The time shift in the temperature pattern observed during anthesis, nighttime during the female phase and daytime during the bisexual and male phases, is probably related to the different biological role of floral thermogenesis in S. foetidus. During the female phase, when stigma are receptive, the heat not only warms the insects, it is also essential to the pollination 
process. It has been shown in a congeneric species, Symplocarpus renifolius, that $23^{\circ} \mathrm{C}$ is the optimal temperature for both pollen germination and pollen tube growth rate (Seymour et al. 2009). Our measurements showed that the average spadix temperature during the female phase was $21.6^{\circ} \mathrm{C}$, therefore close to the optimum, while the mean ambient temperature was $8^{\circ} \mathrm{C}$. During the bisexual and male phases, insects may be warmed before flying away loaded with pollen, particularly during the day when the spadix temperature can reach up to $28.9^{\circ} \mathrm{C}$. During the night, no significant spadix heating seemed to occur, resulting in an average spadix temperature of $12^{\circ} \mathrm{C}$ during the male phase, which is still warmer than the average $8^{\circ} \mathrm{C}$ of the ambient air. Moreover, the decreasing heat in the male phase inflorescences in late afternoon may cause the insects to leave them, while the female phase inflorescences are simultaneously growing warmer and increasingly attracting insects, thus promoting cross-pollination.

In summary, Symplocarpus foetidus is obligatorily cross-pollinated by insects (Diptera and Coleoptera). Its pollination system could be an original combination of breeding site and deception pollinations. The thermogenic spadix also resulted in a significant warming of the air within the floral chamber, particularly during the female phase of anthesis. The reproductive success of the investigated population of $S$. foetidus is low but the main limiting factor(s) are yet to be determined.

\section{Acknowledgments}

The authors wish to thank Léa Bouttier for the use of her photographs in Figure 1. This study was funded in part by a grant from "Les Amis du Jardin Botanique de Montréal" (To D.B., S.P., M.G.), and a grant from the Natural Sciences and Engineering Research Council of Canada (To D.B.). The authors also wish to thank Dr Marion Chartier and an anonymous reviewer for their constructive suggestions for the manuscript. The authors thank Marilyne Tremblay Coutu for linguistic revision and proofreading. 


\section{References}

Barriault, I, D Barabé, L Cloutier, M Gibernau. 2010. Pollination ecology and reproductive success in Jack-in-the Pulpit (Arisaema triphyllum) in Québec (Canada). Plant Biol. 12(1):161-171.

Bröderbauer, D, A Diaz, A Weber. 2012. Reconstructing the origin and elaboration of insecttrapping inflorescences in the Araceae. Am J Bot. 99(10):1666-1679.

Camazine, S, KJ Niklas. 1984. Aerobiology of Symplocarpus foetidus: interactions between the spathe and spadix. Am J Bot. 71(6):843-850.

Chartier, M, M Gibernau, SS Renner. 2014. The evolution of pollinator/plant interaction types in the Araceae. Evolution 68(5):1533-1543.

Gibernau, M. 2016. Pollinators and visitors of aroid inflorescences III - Phylogenetic \& Chemical insights. Aroideana 39(3): 4-22.

Govaerts, R, DG Frodin. 2002. World checklist and bibliography of Araceae (and Acoraceae). Royal Botanic Garden, Kew.

Grimaldi, D, J Jaenike. 1983. The diptera breeding on skunk cabbage, Symplocarpus foetidus (Araceae). New York Entomol Soc. 91(1):83-89.

Hammer, Ø, DAT Harper, PD Ryan. 2001. Past: Paleontological statistics software package for education and data analysis. Palaeontol Electron. 4. 9pp

Hernández-Hernández, T, JJ Wiens. 2020. Why are there so many flowering plants? A multiscale analysis of plant diversification. Am Nat 195(6):948-963.

Ito, K, T Ito, Y Onda, M Uemera. 2004. Temperature-triggered periodical thermogenic oscillations in skunk cabbage (Symplocarpus foetidus). Plant Cell Physiol. 45(3):257-264.

Jaenike, J. 1978. Resource predictability and niche breadth in the Drosophila quinaria species group. Evolution 32(3):676-678. 
Kevan, PG. 1989. How honeybees forage for pollen at skunk cabbage, Symplocarpus foetidus (Araceae). Apidologie. 20:485-490.

Knutson, RM. 1972. Temperature measurements of the spadix of Symplocarpus foetidus (L.) Nutt. Am Midl Nat. 88(1):251-254.

Knutson, RM. 1974. Heat production and temperature regulation in eastern skunk cabbage. Science 186(22 November):746-747.

Knutson, RM. 1979. Plants in heat. Nat Hist. 88(3):42-47.

Kozen, EN. 2013. The scent of eastern skunk cabbage, Symplocarpus foetidus (Araceae): Qualification of floral volatiles and sex differences in floral scent composition. Master Sci, Indiana Univ Pennsylvania. 59 p.

Lee, S, S Lee, K Heo, SC Kim. 2010. Palynological insights of the eastern Asian and eastern North American disjunct genus Symplocarpus (Araceae). J Plant Res. 123:723-729.

Mayo, SJ, J Bogner, PC Boyce. 1997. The genera of Araceae. Royal Botanic Gardens, Kew.

McAlpine, JF, BV Peterson, GE Shewell, HJ Teskey, JR Vockeroth, DM Wood. 1981. Manual of Neartic Diptera Vol 1. Research Branch Agriculture Canada, Hull. 674p.

Moodie, GEE. 1976. Heat production and pollination in Araceae. Can J Bot. 54:545-546.

Nie, ZL, H Sun, H Li, J Wen. 2006. Intercontinental biogeography of subfamily Orontioideae (Symplocarpus, Lysichiton, and Orontium) of Araceae in eastern Asia and North America. Mol Phylogenet Evol. 40:155-165.

Seymour, RS, AJ Blaylock. 1999. Switching off the heater: influence of ambient temperature on thermoregulation by eastern skunk cabbage Symplocarpus foetidus. J Exp Bot. 50(338):15251532.

Seymour, RS. 2004. Dynamics and precision of thermoregulatory responses of eastern skunk cabbage Symplocarpus foetidus. Plant Cell Environ. 27(8):1014-1022. 
Seymour, RS, Y Ito, Y Onda, K Ito. 2009. Effects of floral thermogenesis on pollen function in Asian skunk cabbage Symplocarpus renifolius. Biol Lett. 5:568-570.

Seymour, RS. 2010. Scaling of heat production by thermogenic flowers: limits to floral size and maximum rate of respiration. Plant Cell Environ. 33:1474-1485.

Takahashi, K, T Ito, Y Onda, T Endo, S Chiba, K Ito, H Osada. 2007. Modeling of the thermoregulation system in the skunk cabbage: Symplocarpus foetidus. Physical Rev E. 76(031918):5.

Takeda, S, Y Onishi, Y Fukui, T Ohsako, N Kubo. 2018. Life cycle and genetic diversity of Symplocarpus nipponicus (Araceae), an endangered species in Japan. Plants 7(73):10 pp.

Thorington, KK. 2000. Pollination and fruiting success in the eastern skunk cabbage Symplocarpus foetidus (L.) Salisb. ex Nutt. J Biospheric Sci. 2(1):16.

Trelease, W. 1879. On the fertilization of Symplocarpus foetidus. Am Nat. 13(September):580-581. Uemura, S, K Ohkawara, G Kudo, N Wada, S Higashi. 1993. Heat-production and cross-pollination of the Asian skunk cabbage Symplocarpus renifolius (Araceae). Am J Bot. 80(6):635-640.

Uemura, S, Y Sugiura. 2007. Density-dependent hoarding by rodents contributes to large variation in seed mass of the woodland herb Symplocarpus renifolius. Can J Bot. 37:1675-1680.

Urru, I, MC Stensmyr, BS Hansson. 2011. Pollination by brood-site deception. Phytochemistry. 72:1655-1666.

van der Kooi, CJ, J Ollerton. 2020. The origins of flowering plants and pollinators. Science 368(6497):1306-1308.

Wada, N, S Uemura. 2000. Size-dependent flowering behavior and heat production of a sequential hermaphrodite, Symplocarpus renifolius (Araceae). Am J Bot. 87(10):1489-1494.

Williams, KA. 1919. A botanical study of skunk cabbage, Symplocarpus foetidus. Torreya. 19:2129. 
Table 1. Reproductive success of S. foetidus in terms of fruit and seed sets, according to various experimental designs.

\begin{tabular}{|c|c|c|c|c|c|c|}
\hline & \multicolumn{3}{|c|}{2008} & \multicolumn{3}{|c|}{2009} \\
\hline & $\begin{array}{c}\text { Number of } \\
\text { inflorescences }\end{array}$ & $\begin{array}{c}\text { Number of } \\
\text { infructescences }\end{array}$ & $\begin{array}{l}\text { Number of } \\
\text { seeds }\end{array}$ & $\begin{array}{c}\text { Number of } \\
\text { inflorescences }\end{array}$ & $\begin{array}{c}\text { Number of } \\
\text { infructescences }\end{array}$ & $\begin{array}{l}\text { Number of } \\
\text { seeds }\end{array}$ \\
\hline $\begin{array}{l}\text { Unmanipulated } \\
\text { inflorescences }\end{array}$ & 45 & $6 *(13 \%)$ & $1 ; 4 ; 4 ; 12 ; 30$ & 45 & $14(31 \%)$ & $\begin{array}{c}1 ; 2 ; 3 ; 3 ; 4 ; 6 ; \\
6 ; 8 ; 10 ; 15 ; \\
18 ; 22 ; 25 ; 28\end{array}$ \\
\hline Floral cycle & - & - & $-"$ & 24 & $1 "(4 \%)$ & $0 "$ \\
\hline Insect sampling & 20 & $4(20 \%)$ & $1 ; 2 ; 16 ; 46$ & 15 & 0 & - \\
\hline Thermogenesis & 3 & $1(33 \%)$ & $\mathrm{NC}$ & 1 & 0 & - \\
\hline $\begin{array}{r}\text { Total } \\
\text { Mean } \pm \text { SD }\end{array}$ & 68 & $11(16 \%)$ & $11.6 \pm 11.6$ & 69 & $14(20 \%)$ & $11.6 \pm 11.6$ \\
\hline $\begin{array}{l}\text { Spontaneous self-pollination } \\
\text { (bagged inflorescences) }\end{array}$ & 20 & $2 "(5 \%)$ & $0 " ; 12$ & 20 & $1 "(0 \%)$ & $0 "$ \\
\hline
\end{tabular}

*one infructescence rotten before full maturation. "empty berries with no developed seeds. NC : Not collected. 
Table 2. Number of insects collected in the environment of the studied population (ground plates) and in the inflorescences of S. foetidus (20 in 2008 and 15 in 2009). In 2009, visitors were considered separately according to the inflorescence sexual phase during which they were captured. Taxa comprising more than $4 \%$ of the sampling are in bold. *: at least one specimen was carrying pollen (see Table 3 ).

\begin{tabular}{|c|c|c|c|c|c|c|c|}
\hline & & & & \multicolumn{2}{|c|}{2008} & \multicolumn{2}{|c|}{2009} \\
\hline & & & & Environment & \multirow[t]{2}{*}{ Visitors } & Visitors & Visitors \\
\hline Class & Order & Sub-order & Family & & & $\begin{array}{l}\text { female } \\
\text { phase }\end{array}$ & $\begin{array}{l}\text { male } \\
\text { phase }\end{array}$ \\
\hline \multirow[t]{3}{*}{ Arachnida } & Acarina $^{x}$ & & & 41 & 6 & 0 & 0 \\
\hline & Araneae & & & 57 & 26 & 5 & 19 \\
\hline & Opiliones & & & 7 & 11 & 0 & 0 \\
\hline Malacostraca & Isopoda & & & 0 & 2 & 0 & 0 \\
\hline Collembola $^{\times}$ & & & & 273 & 23 & 4 & 22 \\
\hline \multirow[t]{31}{*}{ Insecta } & Coleoptera & & & 195 & 19 & 6 & 15 \\
\hline & Hemiptera & & & 38 & 7 & 2 & 4 \\
\hline & Hymenoptera & & & 103 & 9 & 0 & 14 \\
\hline & Lepidoptera & & & 18 & 1 & 0 & 2 \\
\hline & Orthoptera & & & 11 & 0 & 0 & 0 \\
\hline & Thysanoptera & & & 0 & 6 & 0 & 2 \\
\hline & Diptera & Brachycera & Anthomyiidae & 17 & 5 & $1 *$ & $4^{*}$ \\
\hline & Diptera & Brachycera & Chamaemyiidae & 0 & 1 & 0 & 0 \\
\hline & Diptera & Brachycera & Calliphoridae & 7 & 0 & 0 & 0 \\
\hline & Diptera & Brachycera & Chloropidae & 16 & 4 & $4^{*}$ & 9* \\
\hline & Diptera & Brachycera & Diastatidae & 0 & 0 & $2^{*}$ & 0 \\
\hline & Diptera & Brachycera & Dolichopodidae & 0 & 0 & 0 & 2 \\
\hline & Diptera & Brachycera & Drosophilidae & 2 & 4 & $3 *$ & $8^{*}$ \\
\hline & Diptera & Brachycera & Dryomyzidae & 0 & 0 & 0 & $4^{*}$ \\
\hline & Diptera & Brachycera & Empididae & 12 & 1 & 0 & 0 \\
\hline & Diptera & Brachycera & Ephydridae & 0 & 0 & $2^{*}$ & 0 \\
\hline & Diptera & Brachycera & Heleomyzidae & 0 & 0 & 0 & 1 \\
\hline & Diptera & Brachycera & Lonchaeidae & 0 & 2 & 0 & $1 *$ \\
\hline & Diptera & Brachycera & Lonchopteridae & 0 & 0 & 0 & 3 \\
\hline & Diptera & Brachycera & Muscidae & 32 & 2 & 0 & 0 \\
\hline & Diptera & Brachycera & Phoridae & 209 & 4 & $5^{*}$ & $8^{*}$ \\
\hline & Diptera & Brachycera & Scatophagidae & 2 & 1 & 0 & 0 \\
\hline & Diptera & Brachycera & Sphaeroceridae & 3 & 1 & $17 *$ & $19 *$ \\
\hline & Diptera & Brachycera & Syrphidae & 1 & 0 & 0 & 0 \\
\hline & Diptera & Brachycera & Tachinidae & 0 & 0 & 0 & 2 \\
\hline & Diptera & Nematocera & Anisopodidae & 0 & 4 & 0 & 0 \\
\hline & Diptera & Nematocera & Axymyiidae & 2 & 0 & 0 & 0 \\
\hline & Diptera & Nematocera & Cecidomyiidae & 22 & 3 & 0 & 0 \\
\hline & Diptera & Nematocera & Culicidae & 3 & 3 & 0 & 0 \\
\hline & Diptera & Nematocera & Chironomidae & 3649 & 177 & $46^{*}$ & $114 *$ \\
\hline & Diptera & Nematocera & Ceratopogonidae & 4 & 0 & 0 & 0 \\
\hline
\end{tabular}




\begin{tabular}{cclcc|c|cc} 
Diptera & Nematocera & Mycetophilidae & $\mathbf{5 7 9}$ & $\mathbf{1 6}$ & $3 *$ & $\mathbf{1 2}^{*}$ \\
Diptera & Nematocera & Psychodidae & $\mathbf{1 9 8}$ & $\mathbf{1 0}$ & 0 & $5^{*}$ \\
Diptera & Nematocera & Sciaridae & $\mathbf{1 7 5}$ & $\mathbf{1 2}$ & 1 & 2 \\
Diptera & Nematocera & Tipulidae & 11 & 2 & 0 & 0 \\
Diptera & Nematocera & Trichoceridae & 31 & 0 & 0 & 0 \\
\hline Total Diptera & & & 4975 & 252 & 84 & 194 \\
\hline
\end{tabular}

$\times$ subclass

Table 3. Pollen loads carried by visiting insects associated with the inflorescences of Symplocarpus foetidus. Number of collected specimens with or without pollen, and average and range of pollen loads per taxonomic group (order or family) during the female and male phases of anthesis.

\begin{tabular}{|c|c|c|c|c|c|c|c|}
\hline \multirow[b]{2}{*}{ Order } & \multirow[b]{2}{*}{ Family } & \multicolumn{3}{|c|}{ female phase (receptivity) } & \multicolumn{3}{|c|}{ male phase (pollen release) } \\
\hline & & $\begin{array}{l}\text { without } \\
\text { pollen }\end{array}$ & $\begin{array}{c}\text { with } \\
\text { pollen }\end{array}$ & $\begin{array}{c}\text { average } \\
\text { pollen load }^{\#} \\
(\min -\max )\end{array}$ & $\begin{array}{l}\text { without } \\
\text { pollen }\end{array}$ & $\begin{array}{l}\text { with } \\
\text { pollen }\end{array}$ & $\begin{array}{c}\text { average } \\
\text { pollen load } \\
(\min -\max )\end{array}$ \\
\hline Coleoptera & & 2 & 5 & $10.8(3-38)$ & 0 & 15 & $56(3-169)$ \\
\hline Hymenoptera & & - & - & - & 10 & 4 & $257(14-500)$ \\
\hline Diptera & Anthomyiidae & 0 & 1 & 90 & 0 & 3 & $219(1-650)$ \\
\hline Diptera & Chloropidae & 1 & 1 & 5 & 0 & 9 & $54.6(2-190)$ \\
\hline Diptera & Diastatidae & 0 & 2 & $2.5(2-3)$ & - & - & - \\
\hline Diptera & Dolichopodidae & - & - & - & 2 & 0 & - \\
\hline Diptera & Drosophilidae & 0 & 2 & $1.5(1-2)$ & 2 & 5 & $12.4(1-52)$ \\
\hline Diptera & Dryomyzidae & - & - & - & 0 & 4 & $4.5(4-5)$ \\
\hline Diptera & Ephydridae & 0 & 2 & $2.5(2-3)$ & - & - & - \\
\hline Diptera & Heleomyzidae & - & - & - & 1 & 0 & - \\
\hline Diptera & Lonchaeidae & - & - & - & 0 & 1 & 56 \\
\hline Diptera & Lonchopteridae & - & - & - & 3 & 0 & - \\
\hline Diptera & Phoridae & 2 & 3 & $1.7(1-2)$ & 3 & 5 & $5.2(5-10)$ \\
\hline Diptera & Sphaeroceridae & 8 & 9 & $9.3(1-27)$ & 3 & 12 & $53.6(1-233)$ \\
\hline Diptera & Tachinidae & - & - & - & 2 & 0 & - \\
\hline Diptera & Chironomidae & 40 & 4 & $5.8(1-8)$ & 98 & 13 & $9(1-29)$ \\
\hline Diptera & Mycetophilidae & 1 & 1 & 6 & 3 & 8 & $10.3(2-44)$ \\
\hline Diptera & Psychodidae & - & - & - & 4 & 1 & 1 \\
\hline \multirow[t]{2}{*}{ Diptera } & Sciaridae & 1 & 0 & - & - & - & - \\
\hline & Total & 55 & 30 & & 131 & 80 & \\
\hline
\end{tabular}

${ }^{\#}$ Calculated only for insects carrying pollen 
Figure 1. Anthesis sequence of the inflorescences of Symplocarpus foetidus with four morphofunctional phases (immature stage not illustrated): A. female phase (receptive stigmas); B. end of the female phase (anthers not exerted but visible on the upper flowers below the tepals); C. bisexual phase (pollen released from upper mature stamens, lower stigmas still receptive); note the fly on the lower left corner; D. male phase (pollen released from all mature stamens, stigmas no longer receptive). Pictures taken by Léa Bouttier (different scale but the average spadix height is $2.3 \mathrm{~cm}$ ).
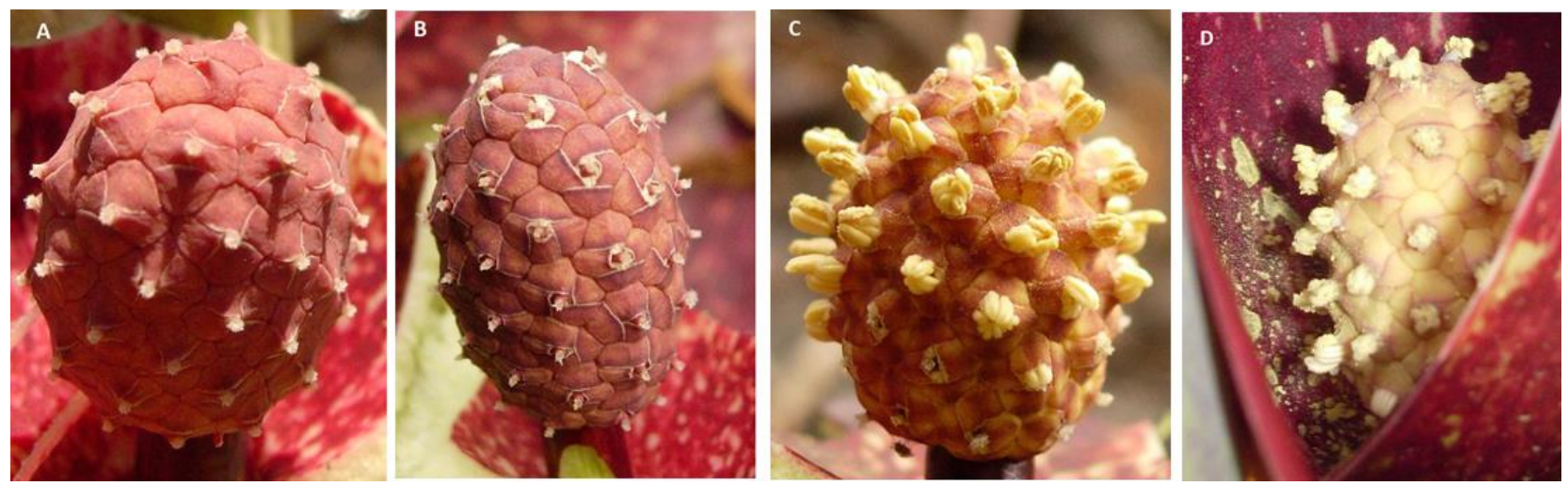
Figure 2. Thermogenic pattern of a shaded inflorescence of Symplocarpus foetidus during the full course of anthesis. A. Temperature curves of the spadix (solid gray line), the air inside the floral chamber (solid black line), and ambient air (dotted line). B. Mean temperature differences between the spadix and ambient air (solid gray line) and between the air of the floral chamber and ambient air (solid black line). The durations of the floral phases of anthesis are indicated above the graphs.
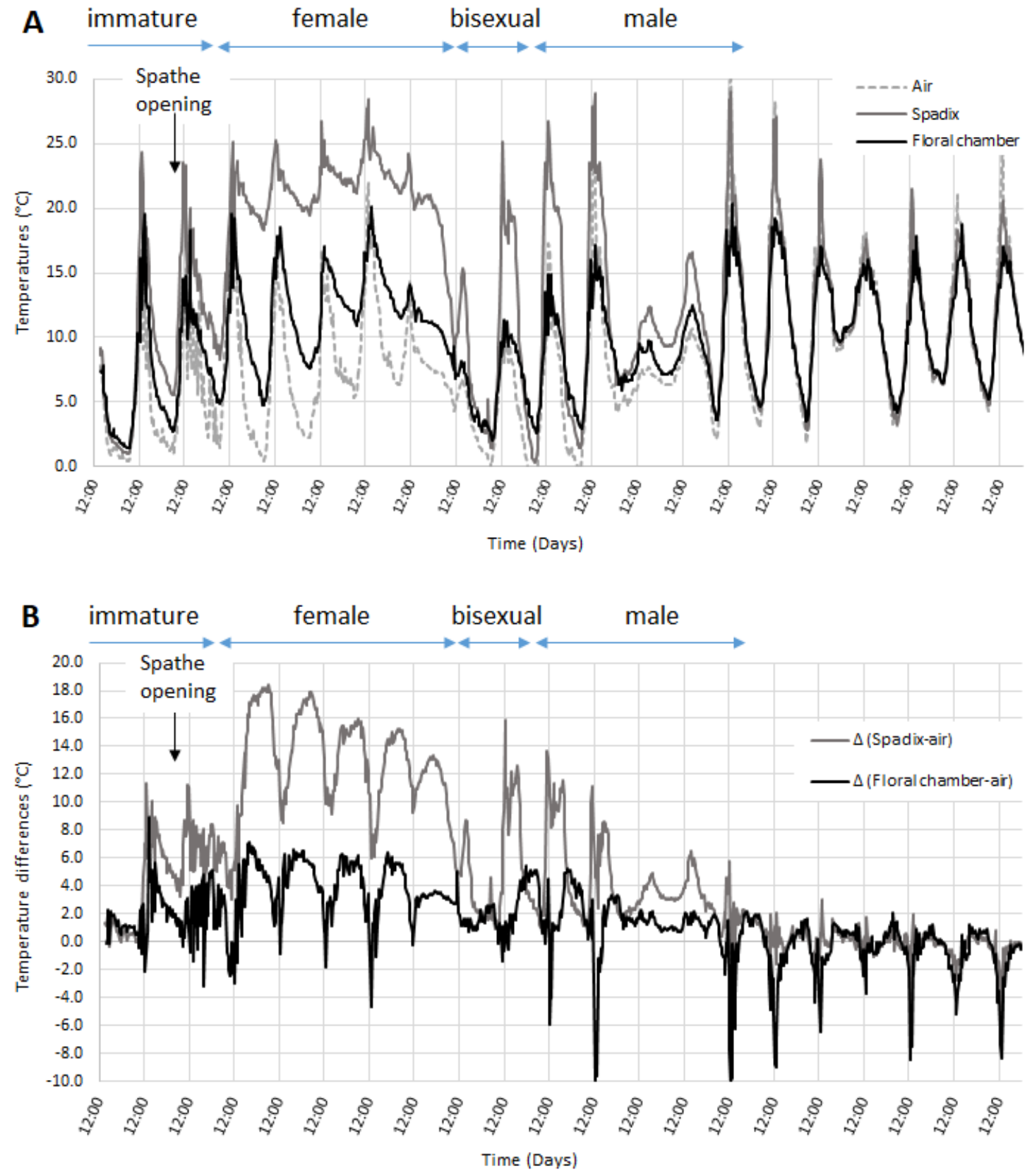